\title{
Postharvest Loss in Rice: Causes, Stages, Estimates and Policy Implications
}

\author{
Sadiya Sadiq Saba and Hassan Ishaq Ibrahim* \\ Department of Agricultural Economics, Federal University Dutsin-Ma, Nigeria
}

Submission: March 21,2018; Published: April 25, 2018

"Corresponding author: Hassan Ishaq Ibrahim, Department of Agricultural Economics, Federal University Dutsin-Ma, Katsina State, Nigeria,

Email: hibrahim@fudutsinma.edu.ng

\section{Introduction}

Rice is the most cultivated crop in the world. It is a major constituent of the diets consumed in many developing countries, and also a stable food in many countries in Africa. In 2006, paddy rice production in sub-Saharan Africa was estimated at 14.2 million tonnes and rice production in this zone grew at $3.23 \%$ per annum from 1961 to 2005 [1]. Studies conducted in Nigeria revealed that rice constitutes over $20 \%$ of total food expenditure among urban and rural households. The demand for rice has grown significantly over the last 40 years due to changing consumer dietary patterns and population growth. In 2014, the annual rice demand in Nigeria was estimated at 5.9 million MT. However, only an estimated 2.7 million MT of milled rice was produced locally, leading to a demand supply deficit that was filled by imports [2].

Postharvest losses represent more than just losses of food. When 20 percent of a harvest is lost, the actual crop loss is just part of the problem. Also wasted are 20 percent of all the factors that contributed to producing the crop, 20 percent of the land used to grow the food and 20 percent of the water used to irrigate it, along with the human labor, seeds, fertilizer, and everything else. In other words, post-harvest food loss translates not just into human hunger and financial loss to farmers but into tremendous environmental waste as well [3].

This review will therefore focus on the following issues:

a. Describe PHL and highlight the stages of Postharvest loss in rice production in Nigeria

b. Describe the causes of Postharvest losses in rice production in Nigeria

c. Review the estimates of postharvest losses in rice production in Nigeria

\section{Postharvest losses explained}

Postharvest loss can be defined as the degradation in both quantity and quality of food produced from time of harvest to the point it is consumed. Quality losses include those that affect the nutrient/caloric composition, the acceptability, and the edibility of a given product. These losses are generally more common in developed countries. Quantity losses refer to those that result in the loss of the amount of a product. Loss of quantity is more common in developing countries as cited by Kiaya [4]. Global estimates of postharvest losses and wastages are presented in Figure 1.

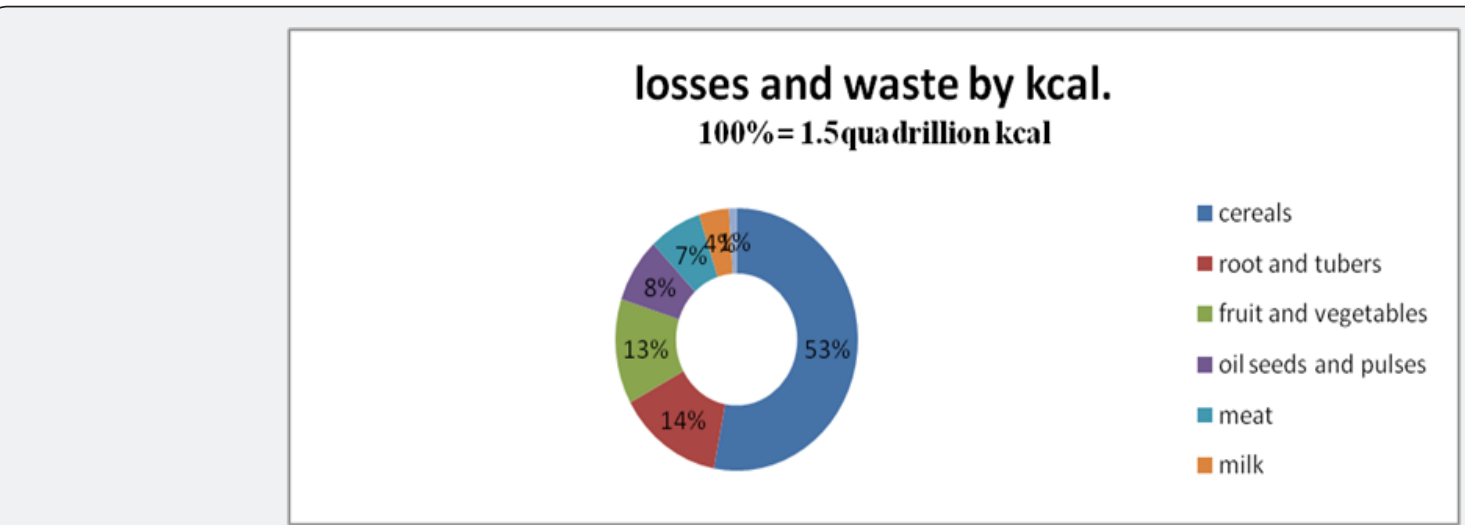

Figure 1: Global estimate of Post harvest losses [4]. 
The term post harvest losses in rice production means any reduction in the amount of edible rice grain due to reduction of availability, edibility, wholesomeness or quality that prevents the rice grains from being consumed by people. Rice grain is lost at every step from harvesting operations to consumption. Post harvest or post production losses of rice occur both on farm and off farm levels. The reduction in the moisture content of rice grain and the removal of inedible portions such as husk and bran in the process of milling are not considered as post harvest losses as cited by Guisse [5]. Loss is a concept which is difficult to define. If losses are determined on the basis of the original weight of the crop, it can lead to an overestimation of losses. On the other hand, there are other losses, which are difficult to determine, and these losses include time, manual labour, agricultural inputs, opportunity cost, illusion and hopes. (FAO 1992) as cited by Folayan [6].

\section{Forms and stages of Postharvest loss in rice}

Table 1: Generic food supply chain and examples of food waste

\begin{tabular}{|c|c|}
\hline Stage & Examples of Waste \\
\hline 1. Harvesting, handling at harvesting & $\begin{array}{l}\text { Edible crops left in field, ploughed into soil, eaten by pests; timing of } \\
\text { harvest not optimal; crop damaged during harvesting }\end{array}$ \\
\hline 2. Threshing & Loss due to poor technique \\
\hline 3. Drying, transport and distribution & $\begin{array}{l}\text { Quality and quantity loss of during drying, poor transport infrastructure; } \\
\text { loss owning to spoiling/bruising }\end{array}$ \\
\hline 4. Storage & $\begin{array}{l}\text { Pests and disease attacks, spillage, contamination; natural drying out of } \\
\text { food }\end{array}$ \\
\hline $\begin{array}{l}\text { 5. Primary processing, cleaning, classification, hulling, pounding, } \\
\text { grinding, packaging, soaking, winnowing, drying, sieving, milling }\end{array}$ & Process losses; contamination in process causing loss of quality. \\
\hline $\begin{array}{l}\text { 6. Secondary processing, mixing, cooking, frying, moulding, cutting, } \\
\text { extrusion }\end{array}$ & Process losses; contamination in process causing loss of quality \\
\hline 7. Product evaluation and quality control & Product disregarded /out-grades in supply chain \\
\hline 8. Packaging & $\begin{array}{l}\text { Inappropriate packaging damages produces; grain spillage from sacks; } \\
\text { attack by pests }\end{array}$ \\
\hline 9. Marketing, selling, distribution & $\begin{array}{c}\text { Damage during transport; spoilage; poor handling; losses caused by poor } \\
\text { storage }\end{array}$ \\
\hline 10. Post-consumer & $\begin{array}{l}\text { Poor storage/stock management; discarded before serving; poor food } \\
\text { preparation; expiration }\end{array}$ \\
\hline $\begin{array}{l}\text { 11. End of life disposal of food waste/loss at different stages in supply } \\
\text { chain. }\end{array}$ & $\begin{array}{l}\text { Food waste discarded may be separately treated, fed to animals, mixed } \\
\qquad \text { with other wastes/land filled }\end{array}$ \\
\hline
\end{tabular}

Source: Parfitt et al. (2010) as cited by Kiaya [4].

Some stages in the rice postharvest system are more critical than others, particularly in tropical and subtropical areas where rice is more vulnerable to damage and more likely to suffer qualitative and quantitative losses. Among these critical stages, drying and storage are especially important. Between $10-40 \%$ of the food that is grown never reaches the market or a consumer's plate because of insects and rodents that get into storage containers, losses during harvesting and processing, market demand for "perfect" unblemished produce, and other factors. Postharvest losses can occur during any of the various stages of post-production system. (FAO 1997) as cited by Taiwo \& BartPlange [7]. The various stages of PHL are further described in Table 1.

According to a study by the Swiss Agency for Development and Cooperation (SDC), postharvest losses occur at different stages such as harvesting, threshing, winnowing, transporting and storage, with storage being the stage at which the biggest loss occurs. Loss also occurs at every stage of the supply chain. Following harvest, about 60-70 percent of food grain is stored on farms for variable periods, normally in traditional structures and at dangerously high moisture levels. This makes them particularly vulnerable to infestations of pests and microorganisms. Significant losses also occur during processing, where the number of mills is insufficient to meet demand, and most processing units are small and use outdated technologies (U.S. Department of State, 2013).

The U.S. Department of State, (2013) also added that the principal PHLs in rice occur during harvesting and handling due to grain shattering and due to spillage during transport. They also arise from bio-deterioration in all steps in the postharvest chain, including storage. Quality of rice is often low because rice is not dried properly and the resulting high moisture content can accelerate spoilage.

\section{Causes of Postharvest losses}

The causes of Postharvest losses, which some estimates suggest could range from 15 to as high as 50 percent of what is produced, are manifold. These include harvesting at an incorrect stage of produce maturity, excessive exposure to rain, drought or extremes of temperature, contamination by micro-organisms 
and physical damage that reduces the value of the product (FAO 1985) as cited by Taiwo [7]. Hodges as cited by Marvin, et al. [8] stated that poor Postharvest handling can lead to both weight and quality losses; and they add that "grains may be scattered, dispersed or crushed during handling and may be subject to bio deterioration." In hot climates, if unfavourable weather prevents sufficient crop drying, then Post Harvest Loss (PHL) increases and molds, mycotoxins and poor quality food can lead to significant health costs and morbidity, particularly for persons already affected with high health risks or disease.

Coker \& Ninalowo [9] revealed that lack of harvesting equipment was the major cause of Postharvest losses. Furthermore, Kiaya [4] pointed out that, as a product moves in the postharvest chain, PHLs may occur from a number of causes, such as improper handling or bio deterioration by micro organisms, insects, rodents or birds. According to Bolarin \& Bosa [10] biological (internal) causes of deterioration include respiration rate, ethylene production and action, rates of compositional changing (associated with colour, texture, flavour, and nutritive value) mechanical injuries, water stress, sprouting and rooting, physiological disorders and pathological breakdown. The rate of biological deterioration depends on several environmental (external) factors such as temperature relative humidity, air velocity and atmospheric composition (concentration of Oxygen, Carbon dioxide and ethylene) and sanitation procedures. The researchers opined that Postharvest losses largely arose from multiple sources, namely pests and diseases, natural disasters, careless human actions and inadequate storage and processing facilities.

Rockefeller [11] believed that the root causes of food loss are interlinked and complex, but the primary drivers include: lack of extension services to build skills in handling, packaging, and storage; insufficient postharvest storage facilities or on-farm storage technologies; and poor market access. However, World Bank [12] shared a view that PHL of grains in SSA can be physical (i.e., volume shrinkage or deterioration of condition), nutritional (notably, grain contaminated with aflatoxin), monetary (i.e. change in unit sales value), or economic (i.e. not being able to access certain markets).

In addition, Bourne (2004) and Atanda et al. (2011) as cited by Chukwuta [3] pointed out that the secondary causes of loss are those that lead to conditions that encourage a primary cause of loss. They are usually the result of inadequate or nonassistant capital expenditures, technology and quality control. Some examples are: inadequate harvesting, packaging and handling skills; lack of adequate containers for the transport and handling of perishables; storage facilities inadequate to protect the food; transportation inadequate to move the food to market before it spoils; inadequate refrigerated storage; inadequate drying equipment or poor drying season; traditional processing and marketing systems can be responsible for high losses; legal standards can affect the retention or rejection of food for human use by being too lax or unduly strict; conscientious, knowledgeable management is essential for maintaining tool in good condition during marketing and storage; and bumper crops can overload the postharvest handling system or exceed the consumption need and cause excessive wastage.

\section{Estimate of post harvest loss in rice}

According to estimates provided by the African Postharvest Losses Information System (APHLIS), physical grain losses (prior to processing) can range from 10 to 20 percent. Estimates of the Postharvest losses of food grains in the developing world from mishandling, spoilage and pest infestation are put at 25\%; this means that one-quarter of what is produced never reaches the consumer for whom it was grown, and the effort and money required to produce it are lost-forever. However estimates of quantitative losses will eventually give a broad picture of where the losses are occurring, their relative scale and how a specific crop has been handled during the post harvest operation. Losses are often estimated as a percentage of the amount remaining from the previous stage of postharvest operation.

Crop production is estimated to account for roughly 70 percent of typical incomes, of which grain crops account for about 37 percent, on average. Recorded production amounts to 112 million tons per year, although records for some crops and some countries are not available. Most grains are produced and consumed by small farming households [12].

Postharvest losses in food crops occurring during harvesting, threshing, drying, processing, storage, transportation, etc. have been estimated to claim between 30 and $40 \%$ of all food crops in developing countries [13].

A study by the International Rice Research Institute IRRI, (2007) in the Philippines has estimated that between 5 to 16 percent of rice is lost in the harvest process, which includes harvesting, handling, threshing, and cleaning. During the Postharvest period, another 5 to 21 percent disappears in drying, storage, milling, and processing. Total estimated losses, not counting later losses by retailers and consumers, run from 10 to 37 percent of all rice grown. FAO reported similar estimates of rice loss in Southeast Asia (FAO, 2007). Quantitative postharvest losses of rice in Sub Saharan Africa are estimated to be between 10 to $22 \%$ while qualitative losses could be as high as $50 \%$. Reducing postharvest losses could help in reducing rice imports with its accompanied economic losses. During the postharvest period, another 5 to 21 percent disappears in drying, storage, milling, and processing. Total estimated losses, not counting later losses by retailers and consumers, run from 10 to 37 percent of all rice grown (De Padua, 1978) as cited by Chukwuta [3].

The Food and Agriculture Organization (1997) reports similar estimates of rice loss in Southeast Asia while other recent scientific surveys place rice losses in China at 5 to 23 percent (not counting processing) (Yong and Algader 1997), and in Vietnam at 10 to 25 percent under typical conditions 
and 40 to 80 percent under more extreme conditions (Phan and Nguyen, 1995) as cited by Chukwuta [3]. According to the Africa Rice Center [1]. Postharvest losses account for 15 to $50 \%$ of the market value of the initial production which equates to a value of $\$ 30$ to $\$ 75$ per ton. In 2004, Postharvest losses were estimated to be about 38,000 tons of milled rice equivalent, a value of $\$ 20$ million per annum. This is not a profitable or sustainable way to farm. In developing countries, Postharvest losses destroy about 15 to 16 percent of the rice crop (FAO, 2004). However, there is insufficient data on postharvest losses of rice with regards to what, where and why the losses occur in the production system [14].

\section{Conclusion and Policy Implications}

With the ban on rice importation in Nigeria, domestic rice production is expected to rise. However, a huge supply and demand gap already exists in domestic rice production. Consequently, if PHL is left unchecked, household food and nutrition security will be affected as evident in the magnitude of the menace. Relevant policies to check post harvest losses are a matter of great urgent necessity if this emerging threat is to be curtailed. Similarly, further studies and research on PHL in food grains especially rice at different handling stages would help assess the extent and magnitude of losses and identify the factors responsible for such losses. This will in turn help develop proper measures to reduce these losses and ultimately prevent food insecurity.

\section{References}

1. Africa Rice Center (WARDA) (2007) Africa Rice Trends: Overview of recent developments in the sub-Sahara, Africa rice sector. Africa Rice Center Brief. Cotonou, Benin: Africa Rice Center (WARDA), Africa, p. 10.

2. Sahel (2015) Rice in Nigeria: Industry Dynamics, A bulletin of Sahel Capital, Volume 12.

3. Chukwunta C (2014) An Analysis of post harvest losses Management Strategies by Farmers in Awgu local government Area of Enugu Stat Nigeria. University of Nigeria, Nsukka.

4. Kiaya V (2014) Post harvest losses and strategies to reduce them: A Technical paper on submitted to Action Contre la Faim (ACF), p. 25.

5. Guise R (2010) Post harvest losses of rice (oriza spp) from harvesting to milling: a case study in Besease and Nobewam in the Ejisu Juabeng district in the Ashanti region of Ghana.
6. Folayan JA (2013) Determinants of Post Harvest Losses of Maize in Akure North Local Government Area of Ondo State, Nigeria. Journal of Sustainable Society 2(1): 2168-2585.

7. Taiwo AA, Plange B (2016) Factors responsible for Postharvest losses and their effects on rice producing farmers a case study of afife and aveyime rice projects in the volta region of Ghana. International Research Journal of Engineering and Technology (IRJET) 3(4): 10141022.

8. Marvin RP, Prasanta KK, Kent DR (2015) Postharvest losses due to harvesting Operations in developing countries: A review of American Society of Agricultural and Biological Engineers Annual International Meeting held at New Orleans, United States, published by American Society of Agricultural and Biological Engineers 1(1): 562-596 ISBN 9781510810501.

9. Coker AA, Ninalowo SO (2015) Effect of Postharvest losses on rice farmers' income in Subsaharan Africa: a case of Niger state, Nigeria. Journal of Agricultural Science and Food Technology 2(3): 27-34.

10. Bolarin FM, Bosa SO (2015) Post Harvest Losses: A Dilemma in Ensuring Food Security in Nigeria. Journal of Natural Sciences Research 5(4): 151-154.

11. Rockefeller Foundation (2015), West Africa. Perspectives to Reducing Postharvest Losses of Agricultural Products in Africa'. A background paper presented at the Feeding Africa conference held at Abdo Diouf International Conference center, Dakar Senegal,West Africa.

12. World Bank (2011) Missing food: The Case of Postharvest Grain Losses in Sub-Saharan Africa. Agriculture and Rural development Unit, Report number 60371-AFR.

13. Saunders RM, Mossman AP, Wasserman T, Beagle EC (1980) A 1978 Survey of Rice Postharvest Losses During Threshing, Drying, Parboiling, Milling, and the Potential for Reducing Such Losses in Developing Countries. In Rice Postharvest Losses in Developing Countries, Agricultural Reviews and Manuals, ARM-W-12, April Oakland, Calif. 94612, Published by Agricultural Research (Western Region), Science and Education Administration, U.S. Department of Agriculture, ISSN 0193-3760.

14. Appiah F, Guisse R, Dartey PKA (2011) Post harvest losses of rice from harvesting to milling in Ghana. Journal of Stored Products and Postharvest Research 2(4): 64-71.

15. Richard W, et al. (2013) Reducing Food Losses and Waste p. Brian L, Craig H, James L, Kitinoja 39.

16. Kader AA (2004) The role of post-harvest management in assuring the quality and safety of horticultural produce. In Food and agriculture organization of the United Nations, Department of Pomology University of California Davis, ISBN 92-5-105137-2.

17. US Department of State (2013) Postharvest Loss Challenges, Discussion Paper, Office of Agriculture, Biotechnology and Textile Trade Affairs, Bureau of Economics and Business Affairs.

Your next submission with Juniper Publishers will reach you the below assets

- Quality Editorial service

- Swift Peer Review

- Reprints availability

- E-prints Service

- Manuscript Podcast for convenient understanding

- Global attainment for your research

- Manuscript accessibility in different formats

( Pdf, E-pub, Full Text, Audio)

- Unceasing customer service

Track the below URL for one-step submission https://juniperpublishers.com/online-submission.php 